\title{
Data, Data, and Yet More Data
}

\author{
William Poole
}

This article was originally presented as a speech at the Association for University Business and Economic Research (AUBER) Annual Meeting, University of Memphis, Memphis, Tennessee, October 16, 2006.

Federal Reserve Bank of St. Louis Review, March/April 2007, 89(2), pp. 85-89.

've long had an interest in data, and I think that this topic is a good one for this conference. The topic is also one I've not addressed in a speech.

A personal recollection might be a good place to begin. In the early 1960s, in my Ph.D. studies at the University of Chicago, I was fortunate to be a member of Milton Friedman's Money Workshop. Friedman stoked my interest in flexible exchange rates, in an era when mainstream thinking was focused on the advantages of fixed exchange rates and central banks everywhere were committed to maintaining the gold standard. Well, I should say central banks almost everywhere, given that Canada had a floating-rate system from 1950 to 1962. Friedman got me interested in doing my Ph.D. dissertation on the Canadian experience with a floating exchange rate, and later I did a paper on nine other floating rate regimes in the 1920s. For this paper I collected daily data on exchange rates from musty paper records at the Board of Governors in Washington.

What was striking about the debates over floating rates in the 1950s is that economists were so willing to speculate about how currency speculators would destabilize foreign exchange markets without presenting any evidence to support those views. In this and many other areas, careful empirical research has resolved many disputes. Our profession has come a long way in institutionalizing empirical approaches to resolving empirical disputes. The enterprise requires data, and what I will discuss is some of the history of the role of the Federal Reserve Bank of St. Louis in providing the data.

Before proceeding, I want to emphasize that the views I express here are mine and do not necessarily reflect official positions of the Federal Reserve System. I thank my colleagues at the Federal Reserve Bank of St. Louis for their comments. Robert H. Rasche, senior vice president and director of research, provided special assistance.

\section{ORIGINS}

The distribution of economic data by the Research Division of the Federal Reserve Bank of St. Louis can be traced back at least to May 1961. At that time, Homer Jones, then director of research, sent out a memo with three tables attached showing rates of change of the money supply (M1), money supply plus time deposits, and money supply plus time deposits plus shortterm government securities. His memo indicated that he "would be glad to hear from anyone who

William Poole is the president of the Federal Reserve Bank of St. Louis. The author thanks colleagues at the Federal Reserve Bank of St. Louis. Robert H. Rasche, senior vice president and director of research, provided special assistance. The views expressed are the author's and do not necessarily reflect official positions of the Federal Reserve System.

(C) 2007, The Federal Reserve Bank of St. Louis. Articles may be reprinted, reproduced, published, distributed, displayed, and transmitted in their entirety if copyright notice, author name(s), and full citation are included. Abstracts, synopses, and other derivative works may be made only with prior written permission of the Federal Reserve Bank of St. Louis. 
thinks such time series have value, concerning promising applications or interpretations." Recollections of department employees from that time were that the mailing list was about 100 addressees.

Apparently Homer received significant positive feedback, since various statistical releases emerged from this initial effort. Among these were Weekly Financial Data, subsequently U.S. Financial Data; Bank Reserves and Money, subsequently Monetary Trends; National Economic Trends (1967) and International Economic Trends (1978), all of which continue to this date. In April 1989, before a subscription price was imposed, the circulation of U.S. Financial Data had reached almost 45,000. A Business Week article published in 1967 commented about Homer that "while most leading monetary economists don't buy his theories, they eagerly subscribe to his numbers." As an aside, as a Chicago Ph.D., I both bought the theories and subscribed to the data publications. By the late 1980s, according to Beryl Sprinkel (1987, p. 6), a prominent business economist of the time, "weekly and monthly publications of the Research Division, which have now become standard references for everyone from undergraduates to White House officials, were initially Homer's products."

Why should a central bank distribute data as a public service? Legend has it that Homer Jones viewed as an important part of his mission providing the general public with timely information about the stance of monetary policy. In this sense he was an early proponent, perhaps the earliest proponent, of central bank accountability and transparency. While Homer was a dedicated monetarist, and data on monetary aggregates have always figured prominently in St. Louis Fed data publications, data on other variables prominent in the monetary policy debates at the time, including short-term interest rates, excess reserves, and borrowings, were included in the data releases.

Early on, the various St. Louis Fed data publications incorporated "growth triangles," which tracked growth rates of monetary aggregates over varying horizons. Accompanying graphs of the aggregates included broken trend lines that illus- trated rises and falls in growth rates. This information featured prominently in monetarist critiques of "stop-go" and procyclical characteristics of monetary policy during the Great Inflation period.

Does the tradition of data distribution initiated by Homer Jones remain a valuable public service? I certainly believe so. But I will also note that the St. Louis Fed's data resources are widely used within the Federal Reserve System. This information is required for Fed research and policy analysis; the extra cost of making the information available also to the general public is modest.

\section{RATIONAL EXPECTATIONS MACROECONOMIC EQUILIBRIUM}

The case for making data readily available is simple. Most macroeconomists today adhere to a model based on the idea of a rational expectations equilibrium. Policymakers are assumed to have a set of goals, a conception of how the economy works, and information about the current state and history of the economy. The private sector understands, to the extent possible, policymakers' views and has access to the same information about the state and history of the economy as policymakers have.

An equilibrium requires a situation in which (i) the private sector has a clear understanding of policy goals and the policymakers' model of the economy and (ii) the policy model of the economy is as accurate as economic science permits. Based on this understanding, market behavior depends centrally on expectations concerning monetary policy and the effects of monetary policy on the economy, including effects on inflation, employment, and financial stability. If the policymakers and private market participants do not have views that converge, no stable equilibrium is possible because expectations as to the behavior of others will be constantly changing.

The economy evolves in response to stochastic disturbances of all sorts. The continuous flow of new information includes everything that happens-weather disturbances, technological developments, routine economic data reports, and the like. The core of my policy model is that 
market responses and policy responses to new information are both maximizing-households maximize utility, firms maximize profits, and policymakers maximize their policy welfare function.

A critical assumption in this model is the symmetry of the information that is available to both policymakers and private market participants. In cases where the policymakers have an informational advantage over market participants, policy likely will not unfold in the way that markets expect, and the equilibrium that I have characterized here will not emerge. Hence, public access to current information on the economy at low cost is a prerequisite to good policy outcomes.

\section{THE EVOLUTION OF ST. LOUIS FED DATA SERVICES}

Data services provided by the Federal Reserve Bank of St. Louis have evolved significantly from the paper publications initiated by Homer Jones. The initial phase of this evolution began in April 1991 when FRED ${ }^{\circledR}$, Federal Reserve Economic Data, was introduced as a dial-up electronic bulletin board. This service was not necessarily low cost. For users in the St. Louis area, access was available through a local phone call. For everyone else, long-distance phone charges were incurred. Nevertheless, within the first month of service, usage was recorded from places as wide ranging as Taipei, London, and Vancouver. ${ }^{1}$ FRED was relatively small scale. The initial implementation included only the data published in U.S. Financial Data and a few other time series. Subsequently, it was expanded to include the data published in Monetary Trends, National Economic Trends, and International Economic Trends. At the end of 1995, the print versions of these four statistical publications contained short histories on approximately 200 national and international variables; initially FRED was of comparable scope.

The next step occurred in 1996 when FRED migrated to the World Wide Web. At that point, 403 national time series became available instan-

1 Eighth Note (1991, p. 1). taneously to anyone who had a personal computer with a Web browser. An additional 70 series for the Eighth Federal Reserve District were also available. The data series were in text format and had to be copied and pasted into the user's PC. In July 2002, FRED became a true database and the user was offered a wider range of options. Data can be downloaded in either text or Excel format. Shortly thereafter, user accounts were introduced so that multiple data series can be downloaded into a single Excel workbook, and data lists can be stored for repeated downloads of updated information. In the first six months after this version of FRED was released, 3.8 million hits were recorded to the web site. In a recent six-month period, FRED received 21 million hits from over 109 countries around the world. FRED currently contains 1,175 national time series and 1,881 regional series. FRED data are updated on a real-time basis as information is released from various statistical agencies.

After 45 years, Homer Jones's modest initiative to distribute data on three variables has developed into a broad-based data resource on the U.S. economy that is available around the globe at the click of a mouse. Through this resource, researchers, students, market participants, and the general public can reach informed decisions based on information that is comparable to the information policymakers have.

In the past year, we have introduced a number of additional data services. One of these, ALFRED ${ }^{\circledR}$ (Archival Federal Reserve Economic Data), adds a vintage (or real-time) dimension to FRED. The ALFRED database stores revision histories of the FRED data series. Since 1996, we have maintained monthly or weekly archives of the FRED database. All the information in these archives has been populated to the ALFRED database, and the user can access point-in-time revisions of these data. ${ }^{2}$ We have also extended the revision histories of many series back in time using data that were

2 We do not maintain histories of daily data series in ALFRED. Interest rates and exchange rates appear at daily frequencies in FRED. In principle, these data are not revised, though occasional recording errors do slip into the initial data releases. Such reporting errors are corrected in subsequent publications, so there is sometimes a vintage dimension to one of these series. 
recorded in U.S. Financial Data, Monetary Trends, and National Economic Trends. For selected quarterly national income and product data, we have complete revision histories back to 1959 for real data and 1947 for nominal data. Revision histories are available on household and payroll employment data back to 1960. A similar history for industrial production is available back to 1927 .

Preserving such information is crucial to understanding historical monetary policy. For example, Orphanides (2001, p. 964) shows "that real-time policy recommendations differ considerably from those obtained with ex-post revised data. Further, estimated policy reaction functions based on ex-post revised data provide misleading descriptions of historical policy and obscure the behavior suggested by information available to the Federal Reserve in real time." Orphanides concludes that "reliance on the information actually available to policy makers in real time is essential for the analysis of monetary policy rules."

Such vintage information also is essential for analysis of conditions at subnational levels. For example, in January 2005 the Bureau of Labor Statistics estimated that nonfarm employment in the St. Louis MSA had increased by 38.8 thousand between December 2003 and December 2004. This increase was widely cited as evidence that the MSA had returned to strong employment growth after four years of negative job growth. However, these data from the Current Employment Statistics were not benchmarked to more comprehensive labor market information that is available only with a lag. ${ }^{3}$ The current estimate of nonfarm employment growth in the St. Louis MSA for this period, after several revisions, is only 11.6 thousand, less than 30 percent of the increase originally reported.

Another data initiative that we launched several years ago is FRASER ${ }^{\circledR}$ — the Federal Reserve Archival System for Economic Research. The objective of this initiative is to digitize and distribute the monetary and economic record of the U.S. economy. FRASER is a repository of image files of important historical documents and serial publications. At present we have posted the entire

3 Wall and Wheeler (2005). history of The Economic Report of the President, Economic Indicators, and Business Conditions Digest. We have also posted images of most issues of the Survey of Current Business from 1925 through 1990 and are working on filling in images of the remaining volumes. The collection also includes Banking and Monetary Statistics and the Annual Statistical Digests published by the Board of Governors, as well as the Business Statistics supplements to the Survey of Current Business published by the Department of Commerce. We are currently working, in a joint project with the Board of Governors, to create digital images of the entire history of the Federal Reserve Bulletin. Finally, we are posting images of historical statistical releases that we have collected in the process of extending the vintage histories in ALFRED back in time. These images should allow scholars, analysts, and students of economic history to reconstruct vintage data on many series in addition to those we are maintaining on ALFRED.

\section{TRANSPARENCY, ACCOUNTABILITY, AND INFORMATION DISTRIBUTION}

As just indicated, the scope of the archival information in FRASER extends beyond numeric data. Ready access to a wide variety of information is essential for transparency and accountability of monetary authorities and the public's full understanding of policy actions. Since 1994, the Federal Reserve System and the FOMC have improved the scope and timeliness of information releases. I have discussed this progress in previous speeches. ${ }^{4}$ Currently, the FOMC releases a press statement at the conclusion of each scheduled meeting and three weeks later follows up with the release of minutes of the meeting. The press release and the minutes of the meetings record the vote on the policy action. The policy statement and minutes give the public a clear understanding of the action taken and insight into the rationale for the action.

Contrast the current situation with the one in 1979. At that time, actions by the Board of

\footnotetext{
4 See, for example, Poole (2005).
} 
Governors on discount rate changes were reported promptly, but there was no press release subsequent to an FOMC policy action and FOMC meeting minutes were released with a 90-day delay. On September 19, 1979, the Board of Governors voted by the narrow margin of four to three to approve a $1 / 2$-percentage-point increase in the discount rate, with all three dissents against the increase. This information generated the public perception that Fed officials were sharply divided and, therefore, that the Fed was not prepared to act decisively against inflation. John Berry (1979, p. A1), a knowledgeable reporter at the Washington Post, observed that "the split vote, with its clear signal that from the Fed's own point of view interest rates are at or close to their peak for this business cycle, might forestall any more increases in market interest rates." However, the interpretation of the "clear signal" was erroneous. On that same day, the FOMC had voted eight to four to raise the range for the intended funds rate to $11^{1 / 4}$ to $11^{3 / 4}$ percent. More importantly, three of the four dissents were in favor of a more forceful action to restrain inflation (see Lindsey, Orphanides, and Rasche, 2005, pp. 195-96). Neither the FOMC's action, the dissents, nor the rationale for the dissents were revealed to the public under the disclosure policies then in effect. The result was to destabilize markets, with commodity markets, in particular, exhibiting extreme volatility.

\section{CONCLUSION}

The tradition of data services was well established when I arrived in St. Louis in 1998, and I must say that I am proud that leadership in the Bank's Research Division has extended that tradition. Data are the lifeblood of empirical research in economics and of policy analysis. Our rational expectations conception of how the macroeconomy works requires that the markets and general public understand what the Fed is doing and why. Of all the things on which we spend money in the Federal Reserve, surely the return on our data services is among the highest.

\section{REFERENCES}

Berry, John. "Fed Lists Discount Rate to Peak of 11\% on Close Vote." Washington Post, September 19, 1979, p. A1.

Business Week. "Maverick in the Fed System." November 18, 1967.

Eighth Note. "Introducing FRED." Federal Reserve Bank of St. Louis, May/June 1991, p. 1.

Orphanides, Athanasios. "Monetary Policy Rules Based on Real-Time Data." American Economic Review, September 2001, 91(4), pp. 964.

Poole, William. "FOMC Transparency.” Federal Reserve Bank of St. Louis Review, January/February 2005, 87(1), pp. 1-9.

Sprinkel, Beryl W. "Confronting Monetary Policy Dilemmas: The Legacy of Homer Jones." Federal Reserve Bank of St. Louis Review, March 1987, 69(3), p. 6.

Wall, Howard J. and Wheeler, Christopher H. "St. Louis Employment in 2004: A Tale of Two Surveys." CRE8 Occasional Report No. 2005-1, Federal Reserve Bank of St. Louis, February 2005. 
